\title{
Fiber Type Specific Expression of Toll-like Receptor4, IL-6, TNF-a, and Suppressor of Cytokine Signaling-3 after Acute Exercise in Rat Skeletal Muscles
}

Won Jun Lee*

Department of Exercise Science, College of Health Sciences, Ewha Womans University, 120-750 Seoul, Korea

Received June 30, 2011 /Revised August 11, 2011 /Accepted August 22, 2011

\begin{abstract}
The purpose of this study was to determine whether a single bout of aerobic exercise affects the expression level of toll-like receptor4 (TLR4), IL-6, TNF-a, and suppressor of cytokine signaling-3 (SOCS-3) expression in rat hindlimb muscles depending on fiber types. To accomplish this, thirteen 7-wk Balb/c male mice were randomly assigned to an experimental group or a control group. The exercise protocol consisted of a single bout of treadmill exercise (inclination $10^{\circ}$, speed $17 \mathrm{~cm} / \mathrm{sec} 10$ $\min , 33 \mathrm{~cm} / \mathrm{sec} 10 \mathrm{~min}, 50 \mathrm{~cm} / \mathrm{sec}$ ) and the animals were killed $24 \mathrm{hr}$ after the exhaustion protocol. The level of TLR4, IL-6, TNF-a, and SOCS-3 mRNA expression was measured by quantitative real-time PCR in soleus and plantaris muscles. A single bout of aerobic treadmill exercise increased TLR4 mRNA expression in the soleus muscle $(p<0.05)$, whereas plantaris TLR4 mRNA expression did not change. Additionally, acute exercise led to a significant increase in IL-6, TNF- $a$, and SOCS-33 mRNA in the soleus muscle, while transcripts of these genes were not affected by exercise in the plantaris muscle. In conclusion, expression level of several immune-related genes such as TLR4, cytokines, and SOCS-3 is regulated by acute exercise in a fiber type specific manner.
\end{abstract}

Key words : Acute exercise, toll-like receptor4 (TLR4), cytokines, suppressor of cytokine signaling-3 (SOCS-3), skeletal muscle fiber type

\section{서 론}

운동은 실행하는 운동의 종류와 강도, 지속시간 등에 따라 골격근의 부피와 근력, 대사적 기능 등에 다양한 변화를 이끌 어 낸다 $[2,9,28]$. 최근에는 운동이 면역반응에 미치는 영향에 대한 연구가 활발히 진행되고 있다. 오랜 기간 동안의 규칙적 인 신체활동 및 유산소 운동은 암과, 만성 염증성 질환, 감염 등으로 인해 발생하는 만성적인 염증반응을 낮추는 항염증 (anti-inflammatory)작용을 한다고 알려져 있다[4,5,29].

면역은 인체 내부 환경이 외부인자인 항원에 대하여 방어하 는 현상으로 태어날 때부터 지니는 선천면역(innate immunity)과 후천적으로 얻어지는 획득면역(acquired immunity)으로 구분된다. 특히 선천면역시스템에서 중요한 역 할을 한다고 알려진 toll-like receptor (TLR)는 유형1 막 신호 분자(transmembrane signaling molecule)로 세포막에 존재하 는 단백질로써 선천면역반응(innate immune response)을 담 당하는 세포에서 주로 발현되며, 미생물의 특이적인 구조를 인식해서 면역 반응을 일으키는 신호를 전달한다[14,15]. 인간 에게는 11 종류의 TLR이 존재하는데 TLR3을 제외한 모든 TLR들은 myeloid differentiation primary response gene 88 (MyD88)이라는 매개 단백질(adaptor protein)에 의해서 하부 신호전달경로가 활성화된다[6]. TLR유전자의 활성화에 따른

*Corresponding author

Tel : +82-2-3277-2563, Fax : +82-2-3277-2846

E-mail : jun@ewha.ac.kr
$\mathrm{MyD} 88$ 의존적인 경로는 전사인자(transcription factor)인 nuclear factor kappa B (NF- $\mathrm{kB}$ )를 조절하고, NF- $\mathrm{kB}$ 가 활성화 되면 핵(nucleus)으로 이동 후 전사인자로서 작용하여 tumor necrosis factor-alpha (TNF-a), interleukin-1 (IL-1), interleukin-6 (IL-6)와 같은 사이토카인(cytokines) 유전자를 발현 시킴으로써 염증 반응을 일으킨다[1,17]. 이러한 면역 반응에 있어서 중추적인 역할을 하는 TLR은 주로 면역세포에서 많은 연구가 이루어져 왔지만, 최근 연구에 의하면 TLR2와 TLR4의 외부 리간드(ligand)로 알려진 lipopolysaccharide (LPS)에 대 한 반응으로 골격근에서도 TLR2와 TLR4 mRNA가 발현된다 는 사실이 보고되었다[20]. 하지만 골격근에서 TLR 발현의 운 동에 의한 조절 기전에 대한 연구는 매우 부족한 실정이다.

운동에 의한 TLR의 반응에 대한 선행연구를 살펴보면 최대 산소섭취량의 $55 \%$ 강도에서 90 분 동안 사이클 운동을 실시한 피험자들의 혈액샘플을 비교 분석한 결과 $\mathrm{CD} 14^{+}$단핵구에서 의 TLR1, TLR2, TLR4 발현이 감소되었다고 보고했으며[18], 노인 여성을 대상으로 한 연구에서도 저항운동 트레이닝의 결과로 단핵구에서의 TLR4 mRNA 발현을 감소시켰으며, LPS에 의한 IL-6와 TNF-a의 생성도 감소시켰다고 보고하였다 [10]. 이와 같은 선행연구를 통해서 적당한 강도의 규칙적인 운동은 면역세포에서 TLR4의 발현을 조절할 뿐만 아니라 IL-6 나 TNF- $a$ 와 같은 하부 목표유전자의 발현까지 감소시킴으로 써 항염증(anti-inflammatory) 효과를 나타내는데 기여한다고 하였다[11,12,13]. 앞서 언급하였듯이 운동이 골격근의 면역반 응 관련 유전자 발현에 미치는 영향에 대한 연구는 부족하며, 
운동의 종류와 강도, 실험방법 등에 의해서도 결과가 크게 영 향을 받는다. 선행연구를 살펴보면 비만 노인들을 대상으로 12 주간 주 3 회 신체 기능 향상을 위한 신체 치료(physical therapy)와 지구성 운동(endurance exercise), 저항 운동(resistance exercise)으로 구성된 운동 프로그램을 실시한 결과 외측광근 (vastus lateralis muscle)에서 TLR4 mRNA 발현이 37\% 감소 하였다고 보고하였다[19]. 이러한 장기간의 운동 프로그램은 사이토카인 IL- 6 와 TNF- $a$ 의 발현도 $50 \%$ 감소시켰다. 또 다른 연구에서는 저항 운동그룹과 유산소 운동그룹으로 나누어 운 동을 실시한 후 근생검을 통해 외측광근과 비복근 (gastrocnemius muscle)에서 염증 사이토카인 IL-6와 TNF-a $\mathrm{mRNA}$ 발현을 분석한 결과 IL-6는 저항운동 후 4 시간 뒤에 가장 큰 증가율을 보였으며, 유산소 운동 또한 저항 운동만큼 의 증가율에는 미치지 못하였지만 발현량을 증가시켰다[22]. 이러한 모든 선행연구들을 종합해 보면 트레이닝에 의한 골격 근에서의 면역반응관련 유전자에 관한 연구는 대부분 장기간 트레이닝에 의한 결과들이 대부분이며, 일회성 운동이 면역관 련 유전자의 발현에 미치는 영향에 관한 연구는 부족한 실정 이다. 최근 근육 조직 및 근육 세포의 형성과정(myogenesis)에 있어 suppressor of cytokine signaling-3 (SOCS-3) 유전자가 중요한 매개체로써의 역할을 한다는 사실이 증명되었다[7,30]. SOCS 유전자들은 여러 조직에서 사이토카인[9], 성장인자 [30], 그리고 호르몬 $[8,14,30]$ 등에 의해 발현이 조절되는데, $\mathrm{C} 2 \mathrm{C} 12$ 근육세포에서 SOCS-3를 과발현시키자 IL-6 전사활성 화가 유의하게 증가되었다. 운동이 SOCS-3 유전자 발현에 미 치는 영향에 대한 연구는 매우 부족한 실정인데, 12 주간의 규 칙적인 트레드밀 운동은 쥐의 족저근(plantaris)과 가자미근 (soleus)에서 SOCS-3 유전자의 mRNA 발현을 증가시켰다고 보고하였다. 하지만 일회성 운동이 SOCS-3 유전자 발현에 미 치는 영향에 대한 연구는 전무한 실정이다.

더 나아가, 골격근에서의 운동에 대한 여러 가지 생리학적 반응을 살펴보기 위해서는 반드시 근섬유 형태에 따른 차이를 고려해야 함에도 불구하고 근섬유 형태에 따른 면역반응 관련 유전자의 발현 변화에 대한 연구는 현재까지 이루어 지지 않 았다. 선행연구에 의하면, 운동 중 지방분해에 의해 증가된 자유지방산은 TLR4 유전자와 신호를 증가시킨다고 보고하였 으며[25], 사이토카인의 수준은 운동의 강도, 시간 등의 영향을 받을 뿐만 아니라 동원된 근육의 수준에 의해서도 영향을 받 는다고 하였다[7]. 또한 근육 내의 글리코겐 수준이 IL-6의 발 현을 조절한다고 하였는데, 골격근의 글리코겐이 낮아질 경우 $\mathrm{IL}-6$ 의 발현이 증가되며[16], 운동 중 글리코겐의 섭취가 근육 의 IL-6 발현증가를 감소시켰다고 보고하였다[8]. 이러한 선행 연구를 바탕으로 본 연구에서는 일회성 유산소 운동 중 근섬 유 형태에 따라 근육의 동원 차이, 운동 전, 후의 글리코겐 수준, 대사적인 측면 등 여러 가지 생리학적 요인들이 차이가 날 것이며, 이러한 차이는 면역관련 유전자의 발현에 있어서
도 근섬유 형태별로 다른 결과를 초래할 것이라는 가정아래 일회성 유산소 운동 후 면역관련 유전자인 TLR4, IL-6, TNF-a, SOCS-3의 발현을 속근과 지근에서 각각 살펴보았다.

\section{재료 및 방법}

\section{실험 대상}

본 연구의 실험은 (주)샘타코 바이오 코리아 실험동물센터 에서 분양 받은 $\mathrm{Balb} / \mathrm{c}$ 수컷 쥐(소: 7 주령, 몸무게 $22.78 \pm 0.27$ g) 13 마리를 대상으로 실험하였다. 실험동물에게는 고형사료 와 멸균된 3차 증류수를 충분히 공급하였으며, 실험 환경은 $12: 12-h r$ 낮과 밤의 사이클에 맞추었으며, 실내온도는 $23 \pm 2^{\circ} \mathrm{C}$, 상대습도 $60 \%$ 를 유지하는 통제된 실험실에서 사육하였다.

\section{실험 설계}

실험동물은 통제군(control, $\mathrm{CON}$ )과 실험군(exercise, EX) 두 집단으로 나누었다. 쥐들은 5 일 동안 동일한 조건에서 적응 운동을 실시하였으며, 5 일간의 적응 훈련이 끝난 후에 통제군 $(\mathrm{CON}, \mathrm{n}=6)$ 과 고강도 일회성 트레드밀 훈련을 실시 할 실험군 $(\mathrm{EX}, \mathrm{n}=7)$ 을 무선 배정하였다.

\section{운동 프로토콜}

본 실험에 앞서 쥐가 트레드밀 운동에 대한 적응훈련의 필요성에 따라 본 운동 전 5 일간 하루 한 번 동일한 시간대 에 속도 $17 \mathrm{~cm} / \mathrm{sec}$, 경사 $0^{\circ}$ 의 조건에서 10 분간 트레드밀에 대한 사전 적응훈련을 시행하였다. 본 운동의 하루 전에는 적응훈련 없이 모든 실험동물이 동일하게 충분한 휴식을 취 하도록 하였다. 본 운동은 실험군 쥐 7마리를 트레드밀 경사 $10^{\circ}$ 고정 후, $17 \mathrm{~cm} / \mathrm{sec} 10$ 분, $33 \mathrm{~cm} / \mathrm{sec} 10$ 분, $50 \mathrm{~cm} / \mathrm{sec}$ 의 속도로 탈진 시까지 운동을 실시하였다. 운동이 끝나는 시점 은 동물에게 가벼운 $0.1 \mathrm{~mA}$ 의 전기충격(electric shock)에도 불구하고 지속적으로 뛰지 않을 경우를 탈진시점으로 규정 하였다. 실험군 쥐의 탈진 시까지 트레드밀 운동 시간은 평 균 $100 \pm 22$ 분이다.

\section{쥐 해부}

고강도 일회성 트레드밀 훈련을 실시한 실험군은 트레드밀 훈련을 실시한 시간으로부터 24시간 후에 근육을 적출하였다. 실험동물은 아이프란액(isoflurane, 하나제약, Korea)을 사용 하여 전신마취 시킨 후, 실험에 사용 할 양쪽 하퇴 가자미근 (soleus)과 족저근(plantaris)을 빠른 시간 내에 분리 한 후 분 석 시까지 $-70^{\circ} \mathrm{C}$ 의 냉동기에 보관하였다.

\section{$\mathrm{RNA}$ 추출 및 $\mathrm{CDNA}$ 합성}

조직 프로세싱 전용 튜브인 CK28 ceramic beads에 Trizol reagent (Invitrogen, Japan) $1 \mathrm{ml}$ 을 넣은 후 $-70^{\circ} \mathrm{C}$ 보관된 조 
직을 튜브에 각각 넣은 후, 프로세싱 기기인 Precellys 24를 사용하여 $6,500 \mathrm{rpm} / 20 \mathrm{sec} / 1$ cycle 프로그램에 맞추어 조직 을 분쇄하였다. 동일하게 갈린 조직을 새로운 튜브에 옮겨 상온에서 5 분간 배양하였으며, 원심분리기 $4^{\circ} \mathrm{C} 12,000 \mathrm{rpm}$ 으 로 5 분간 원심분리 한 후 상층액을 $950 \mu \mathrm{l}$ 분리하였다. 상층 액의 $20 \%$ 인 $190 \mu \mathrm{l}$ 의 chloroform을 처리하여 잘 섞어주고, 상온에서 5 분간 배양 한 후에 $4{ }^{\circ} \mathrm{C}, 12,000 \mathrm{rpm}$ 으로 15 분 동 안 원심분리 하였다. 분리 된 상층액 $350 \mu$ 와 isopropanol를 $1: 1$ 비율인 $350 \mu 1$ 를 넣고 섞어 준 후 상온에서 10 분간 배양 하였다. $4^{\circ} \mathrm{C}, 12,000 \mathrm{rpm}$ 으로 10 분간 원심분리 후 생성된 pellet을 RNase free water로 희석한 $75 \%$ 에탄올 $500 \mu \mathrm{l}$ 넣은 후 $4^{\circ} \mathrm{C} 7,600 \mathrm{rpm}$ 으로 10 분간 원심분리 과정을 거쳐 pellet을 씻어주었다. 최종 추출된 pellet을 $50^{\circ} \mathrm{C}$ 에 1 분 동안 건조한 뒤 RNase free water를 가자미근과 족저근에 각각 $10 \mu \mathrm{l}, 20$ $\mu \mathrm{l}$ 넣어 용해시킨 후, $65^{\circ} \mathrm{C}$ 에 15 분, $4^{\circ} \mathrm{C}$ 에 5 분간 두어 안정화 시켰다. Nano drop기기를 이용하여 UV 흡광도 $260 \mathrm{~nm}$ 에서 최종적으로 RNA 농도를 측정하였다. 농도 측정 후 RNA를 정량하여 통제집단을 비롯한 실험집단 모두 동일하게 $1 \mathrm{\mu g} /$ $\mu \mathrm{l}$ 의 RNA와 5X buffer $4 \mu \mathrm{l}$, Random primer $2 \mu \mathrm{l}, 2.5 \mathrm{mM}$ dNTP $2 \mu \mathrm{l}$, RNase inhibitor $0.5 \mu \mathrm{l}, \mathrm{M}-\mathrm{MLV}$ reverse transcriptase $0.25 \mu \mathrm{l}$ 를 섞어 $25^{\circ} \mathrm{C} 10$ 분 $/ 42^{\circ} \mathrm{C} 60$ 분 $/ 95^{\circ} \mathrm{C} 5$ 분의 조 건으로 polymerase chain reaction (PCR)을 실행하여 $20 \mu \mathrm{l}$ 의 $\mathrm{cDNA}$ 를 증폭, 합성하였다.

\section{정량 실시간 연쇄반응(Real-time quantitative PCR)}

TLR4, IL-6, TNF-a, SOCS-3 messenger RNA (mRNA) 발현 량을 측정하기 위하여 KAPA SYBR®FAST qPCR kit (KAPA Biosystem, USA)를 사용하였으며, 혼합물의 조성은 2X master mixture $10 \mu \mathrm{l}$, ADW $7.2 \mu \mathrm{l}$, cDNA $2 \mu \mathrm{l}$, forward primer, reverse primer 각각 $0.4 \mu 1$ 를 함께 섞어 반응시켰다. 실험에 사용한 primer sequence는 Table 1에 제시하였으며, 모든 Primer는 코스모사(Cosmo Genetech, Korea)에서 제작 및 구 입하여 사용하였다. Real-time PCR 분석은 ABI PRISM 7700 system (Applied Biosystems Inc., USA)을 이용하였으며, 모 든 샘플은 측정값의 신뢰도 확보를 위해 2회 반복 측정하였다. 또한 각각의 target mRNA 발현량은 glyceraldehydes-3phosphate dehydrogenase (GAPDH) mRNA 발현량으로 보 정하였다.

\section{자료 분석방법}

본 연구에서 실시한 트레드밀 운동에 따른 mRNA 발현량 이 유의한 차이가 있는지 검증하기 위하여 window용 SPSS 12.0 프로그램을 이용하여 다음과 같은 방법으로 분석하였다. 고강도 일회성 트레드밀 운동에 따른 쥐의 가자미근과 족저근 의 mRNA 발현 변화를 보기 위해 실시한 real-time PCR 데이 터 값에 대하여 독립표본 $\mathrm{t}$ 검정을 실시하여, 통제집단과 고강 도 일회성 트레드밀 운동을 한 실험집단의 두 집단의 측정값 이 통계적으로 유의한지 검증하였다. 통계적 유의수준은 0.05 로 하였다.

\section{결과 및 고찰}

본 연구는 일회성의 고강도 유산소 운동에 의한 근육의 면 역반응 관련 유전자의 발현변화가 근섬유 형태에 따라 어떠한 차이가 있는지를 규명하고자 하였다. 이러한 실험 목적을 달 성하기 위하여 운동이 끝난 시점에서 24 시간 후에 해부를 통 해 지근섬유인 가자미근(soleus)과 속근섬유인 족저근 (plantaris) 근육을 적출하였으며, 조직 프로세싱 과정을 거친 후 TLR4, IL-6, TNF-a, SOCS-3 유전자의 primer를 사용하여 정량 실시간 연쇄반응(real-time quantitative PCR) 실험 기법 을 이용해 일회성 유산소 운동에 의한 각각의 유전자 전사 정도를 확인하였다.

TLR4는 세포막에 존재하는 막 단백질인 TLR family 중에 하나로써, 세포내부의 신호 전달을 통해 선천적 면역 시스템 에 중요한 역할을 한다[15]. 이러한 면역 반응에 있어서 중추적 인 역할을 하는 TLR은 주로 면역세포에서 많은 연구가 이루어 져 왔다. 최근 연구에 의하면 골격근에서도 TLR2와 TLR4 mRNA가 발현되며[20], 골격근에서 TLR 발현의 운동에 의한 조절 기전에 대한 연구는 매우 부족한 실정이다. 한 선행연구 는 비만 노인들을 대상으로 12 주간 주 3 회 신체 기능 향상을 위한 신체 치료(physical therapy)와 지구성 운동(endurance exercise), 저항 운동(resistance exercise)으로 구성된 운동 프 로그램을 실시한 결과 외측광근에서 TLR4 mRNA 발현이 $37 \%$ 감소하였다고 보고하였다[19]. 또한 다른 선행 연구들 대 부분이 운동이 면역세포의 TLR4에 미치는 영향을 보았으며, 운동 또한 장기간의 유산소 운동 또는 저항운동을 실시하였다 [10-13]. 본 연구에서는 일회성 유산소 운동을 실시하였으며, 이러한 운동이 근육의 TLR4의 발현에 미치는 영향은 근섬유

Table 1. Primer sequences for real-time PCR

\begin{tabular}{|c|c|c|}
\hline Gene & Forward primer & Reverse primer \\
\hline TLR4 & 5'-CAATGGTCAGTGTGATTG-3' & 5'-TTCCTGGATGATGTTGGC-3' \\
\hline IL-6 & 5'-AGTTGCCTTCTTGGGACTGA-3' & 5'-TCCACGATTTCCCAGAGAAC-3' \\
\hline TNF- $a$ & 5'-CCGATGGGTTGTACCTTGTC-3' & 5'-TGGAAGACTCCTCCCAGGTA-3' \\
\hline SOCS-3 & 5'-GGACCAGCGCCACTTCTT-3' & 5'-TACTGATCCAGGAACTCC-3' \\
\hline GAPDH & 5'-ATGACAATGAATACGGCTTACAGCAA-3' & 5'-GCAGCGAACTTTATTGATGGTATT-3' \\
\hline
\end{tabular}


형태 별로 차이가 있었다. Fig. 1에 제시된 바와 같이 TLR4 유전자의 mRNA 발현은 통제군과 비교했을 때 쥐의 가자미근 에서 TLR4 mRNA 발현이 일회성 유산소 운동에 의해 $67 \%$ $(p<0.05)$ 유의하게 증가하였다(CON $1.06 \pm 0.18$ vs. EX $1.70 \pm 0.18)$. 하지만 족저근에서는 $30 \%$ 증가하는 경향을 보였 으나 통계적으로 유의하지 않았다(CON $1.01 \pm 0.07$ vs. EX $1.31 \pm 0.43)$. 이러한 근섬유 형태에 따른 TLR4 전사량 차이의 원인을 설명하는데 있어서 우선적으로 본 연구에서 사용한 운동 프로토콜을 고려해야 한다. 본 연구의 유산소성 트레드 밀 운동은 속근인 족저근에 비해 지근인 가자미근의 산화적 대사에 의한 에너지 소비를 증가시키는 형태의 운동이며, 이 에 따른 지방세포와 지근섬유 조직 내에 저장되어 있던 지방 의 분해 및 자유지방산 사용이 지근에서 더욱 더 증가되었을 것으로 사료된다. 한 선행연구에 의하면 지방분해에 의한 자 유지방산의 사용증가는 TLR4 신호의 증가에 있어서 매우 중 요한 자극요소라고 하였다[27]. 따라서 지근에서 TLR4 유전자 의 유의한 발현 증가는 대사적인 측면에서 지근의 증가된 지 방 산화에 의한 것이라고 사료된다.

TLR4는 리간드인 LPS를 인지하여 세포내부로의 신호 전달 후 매개 단백질 $\mathrm{MyD} 88$ 을 통해서 하부신호전달경로인 NF-kB 를 순차적으로 활성화 시킨다. 전사인자로 알려진 NF-kB가 활성화되면 핵으로 이동 후 작용하여 TNF- $a$ 나 IL-6 같은 염증 사이토카인을 발현시킴으로써 염증반응을 일으키게 한다[1]. 따라서 본 연구에서 일회성 유산소 트레드밀 운동에 의한 지 근에서의 TLR4의 발현 증가가 하부신호전달을 거쳐 IL-6나 TNF- $a$ 와 같은 염증 사이토카인의 발현에 미치는 유의한 영향

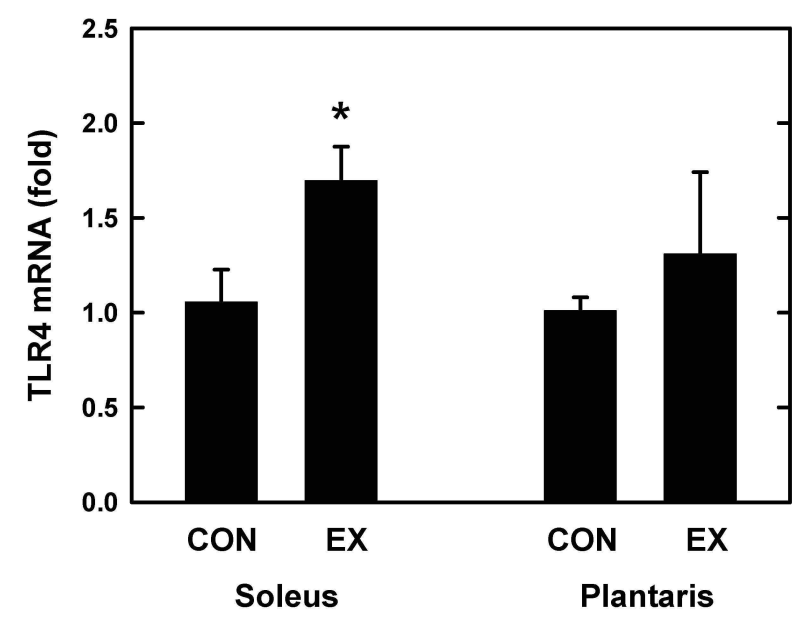

Fig. 1. A single bout of aerobic treadmill exercise (inclination $10^{\circ}$, speed $17 \mathrm{~cm} / \mathrm{sec} 10 \mathrm{~min}, 33 \mathrm{~cm} / \mathrm{sec} 10 \mathrm{~min}, 50$ $\mathrm{cm} / \mathrm{sec}$ ) increased TLR4 mRNA expression in soleus muscle. Target mRNA values are shown normalized to the GAPDH mRNA level for each sample. Samples were analyzed in duplicate in parallel with GAPDH. Significantly different from the control group $(p<0.05)$. Values are means \pm SE. CON, $\mathrm{n}=6 / \mathrm{EX}, \mathrm{n}=7$.
을 미쳤는지를 검증하였다. 결과는 Fig. 2에서 제시한 바와 같 이 일회성 유산소 운동은 쥐의 가자미근에서 염증 사이토카인 IL-6 mRNA 발현이 운동을 하지 않은 통제군에 비해 $83 \%$ $(p<0.05)$ 유의하게 증가하였고(CON $1.23 \pm 0.39$ vs. EX $2.06 \pm$ $0.14)$, 족저근에서는 통계적으로 유의한 차이가 없었다(CON $1.10 \pm 0.25$ vs. EX 2.00 \pm 1.09 ). 일회성 유산소 운동을 실시한 쥐 의 골격근에서 염증 사이토카인 TNF-a 유전자의 mRNA 발현 은 운동을 실시하지 않은 통제군과 비교해 실험군의 가자미근 에서 $108 \%(p<0.05)$ 유의한 증가를 나타냈으며(CON 1.04 0.17 vs. EX 2.16 \pm 0.19$)$, 족저근에서는 통계적으로 유의한 차이 가 없었다(CON $1.14 \pm 0.33$ vs. EX 1.46 \pm 0.63 ) (Fig. 3). 따라서 이와 같은 결과는 지근섬유 TLR4 유전자 활성화에 따른 전사 인자 NF-kB가 활성화되어, 핵으로 이동한 후 목표유전자인 TNF-a와 IL-6를 지근섬유인 가자미근에서 유의하게 증가시킨 것으로 사료된다. 또한 선행연구들은 근육내의 글리코겐 수준 이 IL-6의 발현을 조절한다고 하였는데, 골격근의 글리코겐이 낮아질 경우 IL-6의 발현이 증가되며[16], 운동 중 글리코겐의 섭취가 근육의 IL-6 발현증가를 감소시켰다고 보고하였다[8]. 본 연구의 일회성 유산소 운동은 지근인 가자미근에서의 글리 코겐 사용을 속근에 비해 훨씬 증가시킴으로써 근육 글리코겐 의 저장량을 고갈시켰을 것으로 사료된다. 이러한 낮은 수준 의 글리코겐 저장량이 또한 가자미근에서의 IL-6 증가에 기여 했다고 할 수 있다.

SOCS-3는 사이토카인(cytokine)이나 성장인자(growth factor)들의 세포 내 신호전달을 조절하는데 있어 부적(negative) 반응고리(feedback loop)로 작용하는 유전자로 알려져 있다. 근육세포에서 SOCS-3는 근원섬유의 분화 및 insulin-like growth factor-I (IGF-I)에 의해 민감하게 발현되어 골격근에서

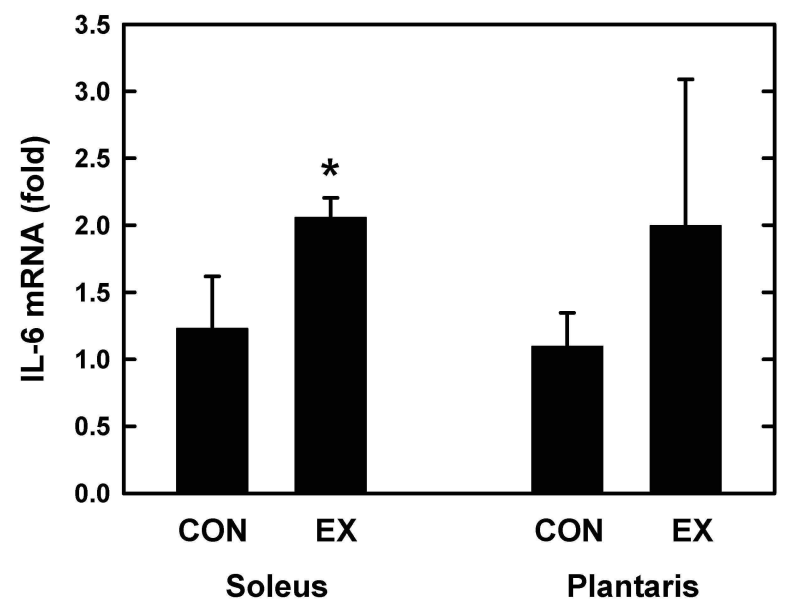

Fig. 2. The effect of a single bout of aerobic treadmill exercise on IL-6 mRNA expression in soleus and plantaris muscle. Samples were analyzed in duplicate in parallel with GAPDH. Significantly different from the control group $(p<0.05)$. Values are means \pm SE. CON, $n=6 / E X, n=7$. 


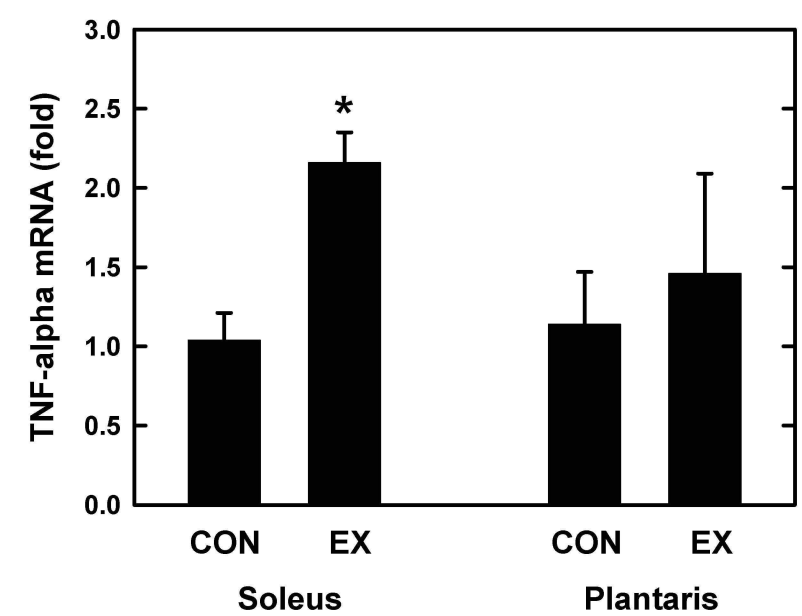

Fig. 3. The effect of a single bout of aerobic exercise increased TNF-a mRNA expression in soleus and plantaris muscle. Samples were analyzed in duplicate in parallel with GAPDH. Significantly different from the control group $(p<0.05)$. Values are means \pm SE. CON, $\mathrm{n}=6 / \mathrm{EX}, \mathrm{n}=7$.

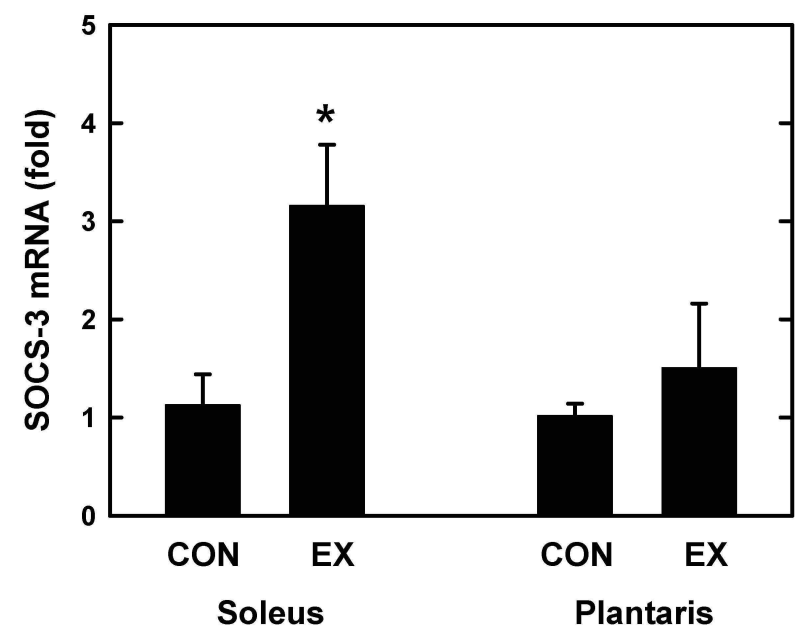

Fig. 4. The effect of a single bout of aerobic exercise increased SOCS-3 mRNA expression in soleus and plantaris muscle. Samples were analyzed in duplicate in parallel with GAPDH. Significantly different from the control group $(p<0.05)$. Values are means \pm SE. CON, $n=6 / E X, n=7$.

다양하게 작용하며, 염증 사이토카인 IL-6의 발현과 밀접한 관계가 있다고 알려져 있다[21,23,24]. Fig. 4에 제시된 바와 같이 일회성 유산소 운동을 실시한 쥐의 가자미근에서 SOCS-3 mRNA 발현은 통제군과 비교하여 약 $200 \%$ ( $p<0.05)$ 유의하게 증가하였다(CON $1.13 \pm 0.31$ vs. EX $3.16 \pm 0.62)$. 반면 일회성 유산소 운동이 족저근에서 통계적으로 유의한 SOCS-3 $\mathrm{mRNA}$ 의 변화를 일으키지는 않았다(CON $1.02 \pm 0.12$ vs. EX $1.51 \pm 0.65)$. 이는 쥐를 대상으로 IL-6의 주입에 의해 SOCS-3 mRNA 발현이 유의하게 증가하였다고 보고한 선행연구와 같 이 본 연구의 트레드밀 운동에 의해 증가된 가자미근 IL-6의
발현이 SOCS-3 유전자의 발현을 유의하게 증가시킨 것으로 사료된다[3].

요약하면, 본 연구는 일회성 유산소 운동이 면역관련 유전 자 발현에 미치는 영향에 있어 근섬유 형태별로 차이가 있음 을 최초로 보여준 데 연구의 중요성이 있다고 할 수 있겠다. 근육에서의 면역반응은 실행한 운동의 종류와 강도에 따라서 달리 나타난다. 이는 운동에 따라 주로 동원되는 근육 형태가 결정되고, 이에 따라 에너지 대사의 비중도 달라짐으로써 면 역반응의 신호가 근섬유 형태에 따라 달리 나타난 것을 밝혔 다는 점에서 연구의 의의가 크다고 할 수 있다. 향후에는 보다 이러한 결과에 대한 보다 명확한 기전적 연구가 실행되어야 할 것이다.

\section{감사의 글}

본 연구의 자료수집을 담당해 주신 박혜림님께 감사를 표합 니다.

\section{References}

1. Akira, S., M. Yamamoto, and K. Takeda. 2003. Role of adapters in Toll-like receptor signaling. Biochem Soc. Trans 31, 637-642.

2. Akima, H., K. Katayama, K. Sato, K. Ishida, K. Masuda, H. Takada, Y. Watanabe, and S. Iwase. 2005. Intensive cycle training with artificial gravity maintains muscle size during bed rest. Aviat. Space. Environ. Med 76, 923-929.

3. Bodell, P. W., E. Kodesh, F. Haddad, F. P. Zaldivar, D. M. Cooper, and G. R. Adam. 2009. Skeletal muscle growth in young rats is inhibited by chronic exposure to IL-6 but preserved by concurrent voluntary endurance exercise. J. Appl. Physiol. 106, 443-453.

4. Brandt, C. and B. K. Pedersen. 2010. The role of exercise-induced myokines in muscle homeostasis and the defense against chronic diseases. J. Biomed Biotechnd. 2010, 1-6.

5. Bruunsgaard, H. 2005. Physical activity and modulation of systemic low-level inflammation. J. Leukoc. Biol. 78, 819-835.

6. Carmody, R. J. and Y. H. Chen. 2007. Nuclear Factor-kB: activation and regulation during Toll-like receptor signaling. Cell. Mol. Immun. 4, 31-41.

7. Febbraio, M. A. and B. K. Pedersen. 2002. Muscle-derived interleukin-6: mechanisms for activation and possible biological roles. FASEB J. 16, 1335-1347.

8. Febbraio, M. A., A. Steensberg, C. Keller, R. L. Starkie, P. Krustrup, P. Ott, N. H. Secher, and B. K. Pedersen. 2003. Glucose ingestion attenuates inerleukin-6 release from contracting skeletal muscle in humans. J. Physiol. 549, 607-612.

9. Fitts, R. H. and J. J. Widrick. 1996. Muscle mechanics: adaptations with exercise-training. Exerc. Sport. Sci. Rev. 24, 427-473.

10. Flynn, M. G., B. K. McFarlin, M. D. Phillips, L. K. Stewart, 
and K. L. Timmerman. 2003. Toll-like receptor 4 and CD14 mRNA expression are lower in resistive exercise-trained elderly women. J. Appl. Physiol. 95, 1833-1842.

11. Gielen, S., V. Adams, S. Mobius-Winkler, A. Linke, S. Erbs, J. Yu, W. Kempf, A. Schubert, G. Schuler, and R. Hambrecht. 2003. Anti-inflammatory effects of exercise training in the skeletal muscle of patients with chronic heart failure. J. Am Coll. Cardiol. 42, 861-868.

12. Gleeson, M. 2007. Immune function in sport and exercise. J. Appl. Physiol. 103, 693-699.

13. Greiwe, J. S., B. Cheng, D. C. Rubin, K. E. Yarasheski, and C. F. Semenkovich. 2001. Resistance exercise decreases skeletal muscle tumor necrosis factor alpha in frail elderly humans. FASEB. J. 15, 475-482.

14. Hashimoto, C., K. L. Hudson, and K. V. Anderson. 1988. The Toll gene of Drosophila, required for dorsal-ventral embryonic polarity, appears to encode a transmembrane protein. Cell 29, 269-279.

15. Kaisho, T. and S. Akira. 2006. Toll-like receptor function and signaling. J. Allergy Clin. Immunol. 117, 979-987.

16. Keller, C., A. Steensberg, H. Pilegaard, T. Osada, B. Saltin, B. K. Pedersen, and P. D. Neufer. 2001. Transcriptional activation of the IL-6 gene in human contracting skeletal muscle: influence of muscle glycogen content. FASEB J. 15, 2748-2750

17. Kramer, H. F. and L. J. Goodyear. 2007. Exercise, MAPK, and NF-kappaB signaling in skeletal muscle. J. Appl. Physiol. 103, 388-395.

18. Lancaster, G. I., Q. Khan, P. Drysdale, F. Wallace, A. E. Jeukendrup, M. T. Drayson, and M. Gleeson. 2005. The physiological regulation of toll-like receptor expression and function in humans. J. Physiol. 563, 945-955.

19. Lambert, C. P., N. R. Wright, B. N. Finck, and D. T. Villareal. 2008. Exercise but not diet-induced weight loss decreases skeletal muscle inflammatory gene expression in frail obese elderly persons. J. Appl. Physiol. 105, 473-478.

20. Lang, C. H., C. Silvis, N. Deshpamde, G. Nystrom, and R. A. Frost. 2003. Endotoxin stimulates in vivo expression of inflammatory cytokines tumor necrosis factor alpha, interleukin-1beta, -6, and high-mobility-group protein-1 in skeletal muscle. Shock 19, 538-546.

21. Lebrun, P. and E. Van Obberghen. 2008. SOCS proteins causing trouble in insulin action. Acta. Physiol. 192, 29-36.

22. Louis, E., U. Raue, Y. Yang, B. Jemiolo, and S. Trappe. 2007. Time course of proteolytic, cytokine, and myostatin gene expression after acute exercise in human skeletal muscle. J. Appl. Physiol. 103, 1744-1751.

23. Pelletier, S., F. Duhamel, P. Coulombe, M. R. Popoff, and S. Meloche. 2003. Rho family GTPases are required for activation of Jak/STAT signaling by G protein-coupled receptors. Mol. Cell Biol. 23, 1316-1333.

24. Rieusset, J., K. Bouzakri, E. Chevillotte, N. Ricard, D. Jacquet, J. P. Bastard, M. Laville, and H. Vidal. 2004. Suppressor of cytokine signaling 3 expression and insulin resistance in skeletal muscle of obese and type 2 diabetic patients. Diabetes 53, 2232-2241.

25. Rosa, J. C., F. S. Lira, R. Eguchi, G. D. Pimentel, D. P. Venancio, C. A. Cunha, L. M. Oyama, M. T. De Mello, M. Seelaender, and C. M. O. D. Nascimento. 2010. Exhaustive exercise increases inflammatory response via toll-like receptor-4 and NF-kappaBp65 pathway in rat adipose tissue. J. Cell Physiol. 13, 1604-1607.

26. Spangenburg, E. E., D. A. Brown, M. S. Johnson, and R. L. Moore. 2006. Exercise increases SOCS-3 expression in rat skeletal muscle: potential relationship to IL-6 expression. J. Physiol. 572, 839-848.

27. Suganami, T., K. Tanimoto-koyama, J. Nishida, M. Itoh, $X$. Yuan, S. Mizuarai, H. Kotani, S. Yamaoka, K. Miyake, S. Aoe, Y. Kamei, and Y. Ogawa. 2007. Role of the toll-like receptor4/NF-kappaB pathway in saturated fatty acid-induced inflammatory changes in the interaction between adipocytes and macrophages. Arterioscler. Thromb. Vasc. Bid. 27, 84-91.

28. Weiss, E. P., S. B. Racette, D. T. Villareal, L. Fontana, K. Steger-May, K. B. Schechtman, S. Klein, A. A. Ehsani, J. O. Holloszy, and Washington University School of Medicine CALERIE Group. 2007. Lower extremity muscle size and strength and aerobic capacity decrease with caloric restriction but not with exercise-induced weight loss. J. Appl. Physiol. 102, 634-640.

29. Weuve, J., J. H. Kang, J. E. Manson, M. M. Breteler, J. H. Ware, and F. Grodstein. 2004. Physical activity, including walking, and cognitive function in older women. J. A. M. A. 22, 1454-1461. 
초록 : 일회성 유산소운동 후 쥐의 골격근에서 toll-like receptor4, IL-6, TNF- a 및 suppressor of cytokine signaling-3의 근섬유 형태 특이적 발현

\section{이원준*}

(이화여자대학교 건강과학대학 체육과학과)

본 연구의 목적은 일회성 유산소 운동이 TLR4, IL-6, TNF-a, SOCS-3 유전자 발현에 미치는 영향을 쥐의 골격 근에서 살펴보는데 있었다. 또한 이러한 일회성 운동의 영향이 근섬유 형태 특이적으로 나타나는 지에 대한 연구 도 수행되었다. 실험은 $\mathrm{Balb} / \mathrm{c}$ 수컷 쥐(1): 7주령, 몸무게 $22.78 \pm 0.27 \mathrm{~g}) 13$ 마리 대상으로 하였으며, 대조군과 운동 군으로 무선배정되었다. 운동은 일회성으로 지칠 때까지 트레드밀 운동(경사도 $10^{\circ}$, speed $17 \mathrm{~cm} / \mathrm{sec} 10 \mathrm{~min}$, $33 \mathrm{~cm} / \mathrm{sec} 10 \mathrm{~min}, 50 \mathrm{~cm} / \mathrm{sec}$ )을 실시하였으며, 운동 후 24 시간이 지난 시점에서 가자미근과 족저근을 적출하였 다. 가자미근과 족저근의 TLR4, IL-6, TNF-a, SOCS-3 mRNA 수준 변화는 real-time PCR을 이용하여 측정하였다. 일회성 유산소 트레드밀 운동은 가자미근에서 TLR4 mRNA 발현을 유의하게 증가시켰지만, 족저근의 TLR4 mRNA 발현에는 유의한 영향을 미치지 않았다. 또한 IL-6, TNF-a, SOCS-3 mRNA 발현은 가자미근에서 일회성 트레드밀 운동에 의해 유의하게 증가되었다. 하지만 족저근에서 이들 유전자의 mRNA 발현은 일회성 운동에 의 해 영향을 받지 않았다. 결론적으로 TLR4, IL-6, TNF-a, SOCS-3와 같은 면역관련 유전자의 발현 수준은 일회성 트레드밀 운동에 의해 근섬유 형태 특이적으로 조절됨을 알 수 있었다. 